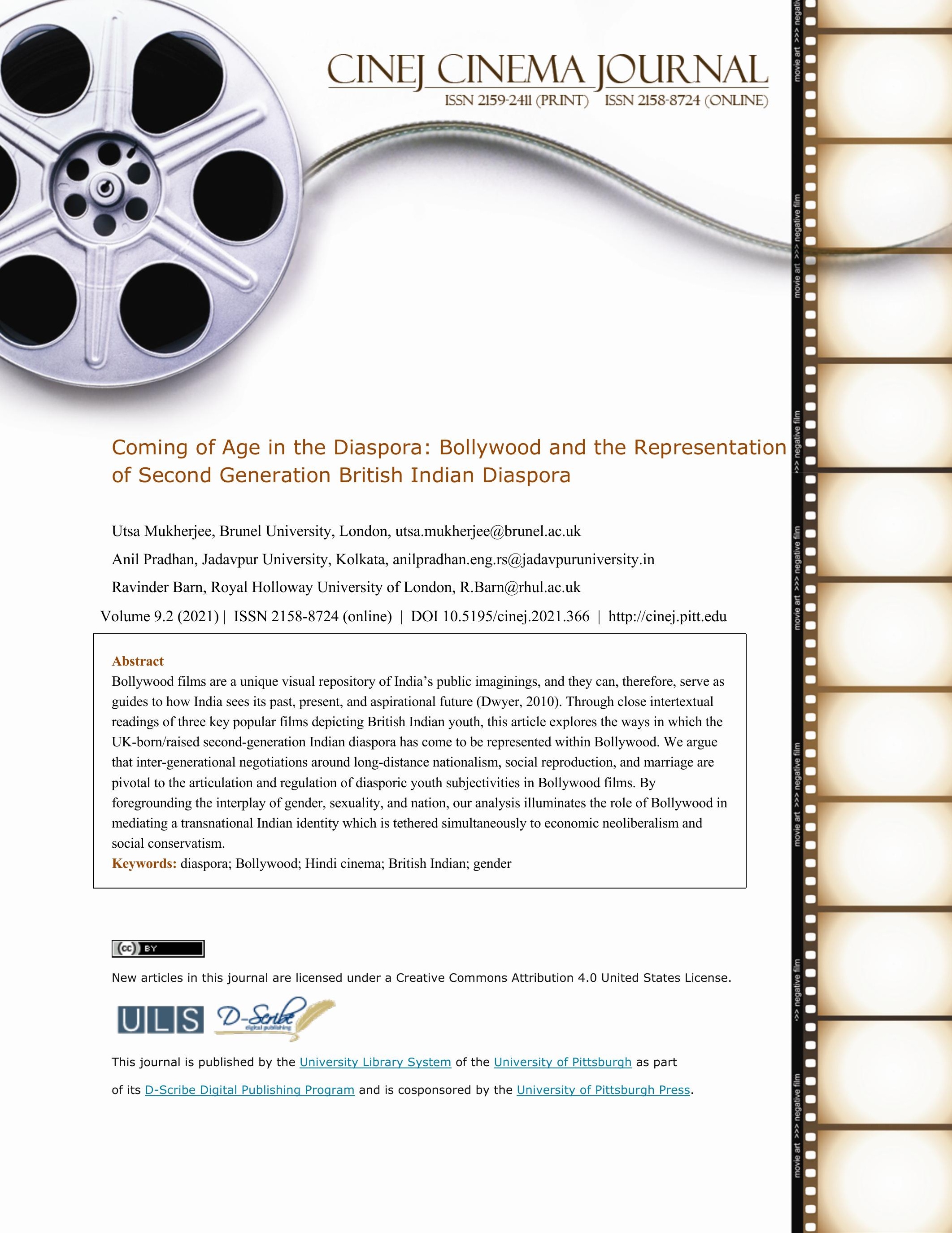




\section{Coming of Age in the Diaspora: Bollywood and the Representation of Second Generation British Indian Diaspora}

Utsa Mukherjee, Anil Pradhan, and Ravinder Barn

\section{Introduction}

Film making in India is more than a century old, but the term Bollywood is a neologism that signifies a diffuse cultural conglomeration or a brand whose global reach has come to be construed as an instrument of India's soft power (Rajadhyaksha, 2003; Thussu, 2016; Vasudevan, 2011b). It is a wider culture industry wherein commercial films occupy only one part, in consort with a swathe of other distribution and consumption activities pertaining to music, dance, fashion, advertising, and radio, among others (Rajadhyaksha, 2003). It is a by-product of the constellation of rapid and far-reaching changes unleashed in India in the early 1990s by economic liberalization and the forces of global capital, with the term itself emerging in the West as a direct consequence of the unprecedented success of diaspora-themed films starting with Dilwale Dulhania Le Jayenge (henceforth $D D L J$ ) in 1995 (Dwyer, 2014; Rajadhyaksha, 2003; Vasudevan, 2011b). It would therefore be anachronistic to apply the term to popular Hindi films made prior to this period. In this article, we draw focus on the first twelve years of Bollywood and unpack three major commercially successful films from this period which had second-generation diasporic youth at the center of their plot. 
Bollywood, as a brand, feeds upon and helps sell the post-economic-liberalization brand 'India' to the world, besides lending itself to the marketing of products as diverse as face creams and academic books (Thomas, 2015; Rajadhyaksha, 2003). Its inordinate length, lack of realism, song-and-dance sequences, extravagant portrayal of religious rituals and family functions, and overarching melodrama have come to invoke the curiosity of the world as a somewhat surreal or comical yet immensely popular art form (Dwyer, 2010; Rajadhyaksha, 2003, Vasudevan, 2011a; Vasudevan, 2011b). Given serious attention, these cultural texts offer insights into the fantasies of the audiences and their visions of a desirable society, but most importantly, they lay bare the travails of Indian modernities in all their features (Dwyer, 2010; Nandy, 1998). The expanding popularity of the term itself attests to its global breadth not only as cinema qua cinema but also as "cinema qua social effects and national cultural coding" (Mishra, 2008, p. 1), standing in as the cultural logic of late modernity in India. In the wake of the bourgeoning scholarship targeted at understanding the political economy and sociology of the Bollywood cinematic institution, Ravi Vasudevan (2011b) has rightly pointed out that the filmic dimensions of the same have received relatively lesser attention, and it is high time that the screen economies and textual practices of these films are brought back under critical scrutiny. Heeding Vasudevan's call, this article pursues a close textual reading of three major Bollywood films - Dilwale Dulhania Le Jayenge (1995), 
Kabhi Khushi Kabhie Gham... (2001), and Namastey London (2007) - in an effort to decode and explicate the cultural politics of Bollywood's representation of second generation British Indian diaspora - a theme underexplored in Bollywood research.

\section{Popular Hindi Films and Indian diaspora}

Diasporic consumption as well as diaspora-centered (sub)plots have been instrumental in the making of Bollywood as we know it today, but Indian cinema in general and popular Hindi cinema in particular has a long and protracted history of engagement with the idea of diaspora beginning not least in the silent era with D. N. Ganguly's Bilat Pherat (England Returned, 1921). It was much later, in the 1960s, that Hindi films in color made overseas locations popular backdrops for travel and romantic song-and-dance sequences without the central characters themselves being residents in those countries. Films such as Love in Tokyo (1966), Around the World (1967), and An Evening in Paris (1967) are some of the prominent instances. Later, a number of popular Hindi films such as Purab Aur Paschim (East and West, 1970) and Hare Rama Hare Krishna (1971) had diasporic characters at the center of the plot, serving to bolster a reductive East versus West dichotomy wherein India and its steadfast citizens embodied a spiritual and moral superiority over the materialistic West characterized by pervasive moral degeneration. The second-generation 
diasporic youth too were caricatured and even demonized as hedonistic, deracinated, and recalcitrant - often with a comically anglicized Hindi accent - who had no right to the cultural citizenship of India. These films also depict a gulf between first-generational diasporans and their children - who constitute the second-generation diaspora - especially in terms of world-views and social networks. However, the entire landscape in this regard was transformed in the mid-1990s, with the articulation of a globalized cinematic product that came to be called Bollywood and which purposefully targeted the diasporic audience as a major source of revenue (Rajadhyaksha, 2003, Vasudevan, 2011a). The three films that we discuss here will help us to appreciate this dynamic around the representation of second-generation diaspora produced in the wake of the 'Bollywoodization' (Rajadhyaksha, 2003) of popular Hindi cinema.

British Indian Diaspora, Young People, and Cultural Representation

Indian presence in Britain can be traced back to the Jacobean period (Habib, 2006; Visram, 1986),

but it grew significantly after the establishment of the British Empire in India with Indians travelling to and working in different parts of Britain throughout the Victorian period and beyond (Nasta, 2013; Visram, 1986). After the Second World War, a large number of people from the Indian subcontinent migrated to the UK, firstly as rights-bearing commonwealth citizens, 
subsequently through employment vouchers and, more recently, via visa-controlled immigration regimes. Today, British South Asians constitute one of the largest ethnic minority sections of the UK population, with Indians being the largest group within the South Asian cohort (Office for National Statistics, 2014). Indian children and young people born or brought up in the UK - the second generation of British Indians - have come to be imagined around the nexus of age, gender, and ethnicity. In scholarly debates, their lived experiences in the British society have been described as 'critically' different from those of their parents (Huq, 2003). Such differences were historically ascribed to the dissonance in the cultural expectations and social demands made of them by their family on the one hand and the larger British society on the other (Ghuman, 1994), resulting in them being caught up between 'two cultures' (Anwar, 1998), often embodying the best or the worst of both 'worlds' (Ghuman, 1991). However, the next generation of scholarship (Baumann, 2004; Huq, 2003) has criticized these conclusions for their sweeping generalizations and simplification of the issues that impinge upon the lived experiences of second-generation British Indian youth. They further argued that these earlier dominant framings have rendered the British Indian youth as a one-dimensional other bereft of agency and reduced the debates to static notions of 'community' and 'culture.'

In the UK, British South Asian youth popular cultural products including music, films, performative arts, literature, and television programs have emerged in this milieu to challenge 
mainstream assumptions and facilitate alternative imaginings. Films such as My Beautiful Launderette (1985), Sammy and Rosie Get Laid (1987), I'm British But ... (1989), Bhaji on the Beach (1993), Bend it like Beckham (2002), and Anita and Me (2002) are a few examples of cinematic texts that speak to and of British South Asian young people's experiences and aspirations. These cultural texts produced in the diaspora offer the British Indian diaspora's manifold estimations of itself by encoding a plethora of lived experiences and deploying diverse forms of narrative expressions. More than just a strategic exercise in 'diasporic memory' or a means to keep in touch with that part of their British Indian identity which is far away (Bose, 2017), these cinematic narratives are sites where British Indian identity is asserted and cultural hybridity is recognized as a way of being British - one that challenges skewed conceptions of Britishness (Modood, 2007). On the other hand, Bollywood - which is often posited as a counterpoint to the hegemony of Western cultural industries - drives home Indian popular culture's rendering of diasporic youth subjectivities, in the process offering insights into how India maps its diasporic youth and why it has come to require diasporic narratives at a time when it is seeking to recalibrate its position and branding in the era of global capital. On account of its global box-office success and the positive perception it creates of India among overseas audiences, Bollywood has already been described as an Indian soft power (Thussu, 2016), but we want to 
expand this analytical framework and treat Bollywood as a key player in India's diaspora strategy.

Diaspora strategy refers to efforts made by states as well as other social actors to mobilize diasporas for economic development and/or nation building by tapping into the latter's human capital and business links (Ho, 2011; Ho, Hickey, \& Yeoh, 2015). The Government of India has, over the years, pursued policies aimed at erecting infrastructures of engagement with its emigrant population, constructing India as a homeland with a diaspora (Mani \& Varadarajan, 2005; Raj, 2015). Our analysis of Bollywood's diasporic narratives is, therefore, embedded within the argument that Bollywood in its own right is an active participant in India's diaspora strategy. The generational lens we bring to bear on these cinematic texts further illuminates how the representational economy of these films push forward India's diaspora strategy - as envisioned by the state and aided by capital.

$D D L J$ and the Re-articulation of the Diasporic Youth

The emergence of brand Bollywood in the mid-1990s is often dated to the release and success of $D D L J$ in 1995, a film which set the ball rolling (Dwyer, 2014; Rajadhyaksha, 2003), and hence, it serves as our point of departure. However, $D D L J$ did not conjure up the entire cinematic mechanism of Bollywood from nowhere. Instead, Bollywood was a beneficiary and a product of the shifts that were already underway as far as Hindi popular cinema was concerned. The 1988 
box-office success of Qayamat Se Qayamat Tak (From Apocalypse to Apocalypse) revived the romantic musical film at a time when Hindi cinema were transfixed to the genre of action-films, thus paving the way for new types of romantic musicals to emerge in the 1990s (Dwyer, 2000). The next watershed moment came with director Sooraj Barjatya's 1994 release Hum Aapke Hain Koun..! (Who am I to You...!; henceforth $H A H K$ ) which succeeded in bringing mass audience back to the cinema halls adding to the financial strength of the film industry (Dwyer, 2014). $H A H K$ also re-invigorated the exhortations of the patri-virilocal family and of patriarchal 'family values' in Hindi films. The extended family and friends in the film not only celebrated every occasion with much ardor but also the lovers Prem and Nisha were ready to prioritize their family at the cost of their own romantic affair. These thematic templates coupled with the fresh doses of film financing and restructuring, that came with the liberalization of the Indian economy in 1991, provided the context within which diasporic Indians as central characters and passionate upholders of so-called 'Indian values' took shape within Bollywood narratives. By doing so, films such as $D D L J$ cemented the emergent genre of the 'family film' that played a discursive role in re-imagining and re-producing notions of the 'Indian' family as well as the nation-state (Joshi, 2014).

Directed by Aditya Chopra, $D D L J$ achieved unprecedented box office, leaving previous records far behind (Mehta, 2011). The film tells the story of two heterosexual British Indian youth, 
namely Simran and Raj. Their parents had emigrated to the UK from India in their late youth, and both Simran and Raj were born and raised in London. They meet while on a tour of Europe with their friends. During the tour, they get stuck in a small town after missing their train to Zurich, which their friends had boarded. This point of crisis provides the opportunity in the plot for Raj and Simran to travel by road in each other's company. The narratives of self-disclosures that mediate their growing friendship are often punctuated by commentaries on their Indian diasporic identity. For instance, as they make their way to Zurich, Raj's rented car breaks down, and they have to arrange for accommodation for the night. Simran refuses to share the only room available with Raj and storms out of it to spend the night in a barn. Raj follows her there and decides to stay with her. Simran ends up getting drunk and wakes up the next morning in bed with her clothes changed and their clothes from the previous night scattered around the room. She suspects that they had sex last night, and Raj feigns their intimacy with lipstick marks on his chest. When Simran starts crying, Raj reveals that it was a joke and adds, "I am an Indian and I know what an Indian woman's izzat is. I cannot commit such an act even in my dreams." The concept of 'izzat,' which literally translates as honor, bears particularly gendered connotations in South Asia and underpins the reputation not only of an individual but also of their family, ethnic group, or religious community. Through such invocations, Bollywood films such as $D D L J$ have cemented a rather simplistic and patriarchal framework of Indian traditions and cultural values that the diaspora - 
especially the second-generation on whom the onus of culture lies - must adhere to, thus turning the cinematic text into a "portable 'package' for survival abroad," a 'homing' strategy invested in/through scenes and dialogues dealing with 'izzat' (Brosius \& Yazgi, 2007). The gendered and sexual politics of diasporic identity also comes alive in an anecdote that Raj shares with Simran in their hired car. Upon enquiring why Raj keeps addressing Simran as 'señorita,' he reveals that his first girlfriend was from Spain, and their relationship ended because she did not like Indians. The racial encoding of sexual and gendered relations, therefore, gets woven into the self-consciousness of diasporic youth in $D D L J$ as they navigate racial hierarchies in their everyday geographies.

Simran had gone for this month-long trip with her friends after ardently appealing to and receiving the permission of her father Baldev Singh - the patriarch of the family. She was betrothed to Baldev's friend Ajit Singh's son Kuljeet twenty years ago, when they were both toddlers. It was in the shadow of Ajit's latest letter asking for the wedding to be arranged that Simran appealed to her father to let her live out her "lifetime in the span of a month" before she marries a man she has never met and settles down in India. Baldev bears the promise of returning to his native land of Punjab, and his diasporic experience is refracted through that nostalgia as he prides himself of keeping India alive in the heart of London. In a very suggestive scene, the moment Baldev rings the doorbell, his daughters change the music in the cassette player from the western beats, that 
they and their mother were dancing to, to an old Hindi film song "Gham Diye Mustaqil Kitna Nazuk Hai Dil..." (Given me unending grief, not realizing how fragile the heart is...) sung by the actor-singer K.L. Saigal in the 1946 film Shahjehan (dir. Abdul Rashid Kardar) - the song itself emerging here as a marker of fragility of cultural identities in the diaspora. At the end of this scene, Baldev tells his wife Lajjo, “I say Lajjo, thank God that you and your daughters haven't fallen into this business of Englishness. Else, you would have been neither here nor there." This conceptualization of belongingness and nation, that one needs to choose a fixed and singular form of cultural affiliation over others in order to retain integrity of identity in the diaspora, is moored in the disciplining and control of desires and movement of gendered diasporic bodies. Parenting strategies and social reproductive work are depicted here as key to maintaining cultural and generational boundaries within diasporic families. Baldev announces that he has not failed in his project of inculcating his 'culture' in his daughter when she runs away from the living room after reading Ajit's letter about their marriage. He interprets this as Simran's display of shyness in front of her father, but upon returning from Europe, she reveals that she has fallen in love with a man she met on the trip. This revelation is met not only with the patriarch's disapproval and rejection but Baldev also instantly takes the decision to take her and the entire family to India for good the first thing next morning. As she goes to India and is preparing for her impending nuptial with 
Kuljeet, Raj meets Simran in the mustard fields of her ancestral village in Punjab. Simran implores

Raj to elope, to which he replies as such:

I am not eloping. I haven't come here to steal you. I might have been born in England, but I am an Indian. I have come here to make you my bride. I will take you away from here only when your father gives me your hand.

This is exactly how the crisis in the plot is eventually resolved. The synecdoche foregrounds the embodied transactions that are being played out by means of Simran, a diasporic female subject, who has to convince her father and receive his permission to travel to Europe, who has to be given away by the father and taken away by the groom as the very title of the film (The Brave Heart Will Take Away the Bride) suggests. Hence, the agency and moral success of the diasporic male is dependent in every instance on the control of the diasporic female subject and her desires. These negotiations are also generational in character, since they are anchored in fatherdaughter (i.e. inter-generational) relationships.

Notwithstanding these overarching constraints crystallizing the sway of heteropatriarchy throughout the text, the possibilities of agency and resistance on the part of female subjects are not altogether foreclosed. While observing 'karva chauth' - a north Indian Hindu annual festival where married, and in this case, engaged, women fast throughout the day, breaking it after seeing 
the full moon and drinking water from the hand of their husband or fiancé - Simran feigns a swoon to avoid breaking the fast by receiving a drink of water from Kuljit. Raj rushes to sprinkle water on her eyes and offers her the first drink, as she winks at him to secretly disclose her ploy. The performance of the ritual is accompanied by a background chorus of female voices singing "Chaand ko dekhoon, haath main jodoon. Karva chauth ka vrat mein todoon. Tere, haath se, peekar paani daasi se ban jaoon rani” (I look at the moon, I pray with folded hands. Then I break my fast. By drinking water from your hands, I become a queen from a slave). Despite the ingrained heteropatriarchal framing of the background music, Simran's act can be construed as a display of, what Shakuntala Banaji in the context of Indian children's lives has termed, ephemeral agency (Banaji, 2017). To talk of ephemeral agency is to acknowledge the fact that agency is always context-dependent and its expression is embodied and intermittent, existing, in a Giddensian sense, as a potential rather than as an ontological quality. Another similar instance is presented when Simran's mother Lajjo takes Simran and Raj aside, gives them all her precious jewelry in a bundle, and pleads them to elope. She had earlier requested Simran to forget about Raj and sacrifice her love for the happiness of all, noting that all her life, she has made sacrifices as a daughter, sister, and wife and that despite her promise to herself that her daughter will live her life as she wishes, she has come to realize that "a woman does not even have the right to make promises." However, she has realized her folly and adds this: 
My daughter won't sacrifice her happiness. She is not going to sacrifice her love. I know Raj, you will make my daughter very happy. You have my blessings. Take her away ... [.] No one here understands your love. Take her from here. I will take care of everything... I beg of you, my son!

Raj refuses to elope, saying he wants Simran's father to give him her hand in marriage and does not want to steal her. Though Lajjo invests causal agency in Raj, begging him to 'take her away' - he being the active subject and she being the consenting object, there is an evident defiance at play here. Lajjo's 'ephemeral agency' cannot very easily be translated into the idiom of rebellion, but it certainly ventilates a feminist reflexivity about patriarchy and about the workings of the gendered and generational subject position within the patriarchal order of family and society.

Seen from a historical perspective of Hindi popular cinema, Raj and Simran, as diasporic central characters, are quite distinct from many diasporans who have featured in previous Hindi films. Purab Aur Paschim (East and West, 1970) had two UK-born British Indian siblings: the brother Jatin who had changed his name to Orphan and appeared in bohemian clothes while the sister Preeti is introduced for the first time covered in a fog of cigarette smoke and blond hair. Both siblings struggle with Hindi and have no understanding of Hindu religious texts or cultural practices such as touching of elder's feet as a mark of respect. This lack of cultural knowledge is 
presented throughout the film as shortcomings and failures, as they self-identify as British and not Indian and, therefore, become the foci of caricature. Another pre-Bollywood film worth mentioning here is the 1991 release Lamhe (Moments), directed by Yash Chopra - DDLJ director Aditya Chopra's father. It centers around Viren, a wealthy businessman from Rajasthan, who lives in London. In a scene in a London cafeteria, Pooja - who is secretly in love with Viren - has a conversation with Anita, Viren's fiancée. They begin by talking about Daijaan (literary meaning governess or midwife) who had been Pooja's foster parent after her parents died in an accident: Anita: How's Daijaan? Pooja: Very well.

Anita: Aren't you a bit too fond of her?

Pooja: Other than her, I don't have anyone else in this world!

Anita: Why are you so emotional?

Pooja: [Chuckles] Because I am an Indian. If you were not born and brought up here, you too would have been emotional.

Though Anita speaks Hindi fluently and is a far cry from Purab Aur Paschim's Preeti, she is still marked out by her behavioral 'lack;' Indianness here gets crafted as a cultural identity tethered not only to linguistic and cultural competence but to an emotional intelligence irreproducible in the diaspora as Indians continue to wield the yardstick that demarcates and differentiates the cultural location of diasporans. Therefore, what $D D L J$ did was to 'redeem' and 'validate' (Mehta, 2011) the diasporic Indian, not only as a rightful Indian national subject but also to portray them as an exemplar extraordinaire of what such a subject hood entails in Indian popular 
imagination. In $D D L J$, it is the Punjab-born and based Kuljit who becomes the foil against whom the 'Indian-ness' of British Indian Raj and Simran is exemplified. Hence, 'Indian-ness' is produced in relation to a difference - a difference which is not only horizontal but also vertical. By horizontal difference, what we mean is that in the context of diasporic populations, difference is conveniently precipitated vis-à-vis the 'non-Indian' ethnic majority with whom they share the everyday social space, but when the diasporic individual is contrasted with the citizen-resident of the so-called 'homeland,' the difference is graded on a vertical scale. In $D D L J$, the repertoire that signifies legitimate membership of Indian identity includes a command over the parents' language, a taste for the cuisine, respect for elders, and participation in and observation of religious ceremonies including 'karva chauth.' Raj and Simran eventually pass the check-list, and it is then that they literally catch the train back to England. The instance where Raj fakes his headache to get himself a crate of beer from Baldev's store in London, he becomes the errant British Indian youth who has not only let down his cultural heritage but has also given a bad name to the community. Raj is gradually redeemed through his acts of compassion, such as attending to a pigeon wounded by Kuljit and his outward chivalry to win away the bride. These culturally loaded signifiers that attest to nation-ness and tradition come saddled with an unrelenting faith in benevolent patriarchy. The patriarch Baldev's iron hand is not undermined but is re-enforced by his call to his daughter: "Ja 
Simran ja, jee ley apni zindagi”" (go Simran go, and live your own life). If Baldev is the torch bearer

of Indian tradition and culture, then he has for an uneasy companion Dharamvir, Raj's father, who doesn't hesitate to share a drink with his son and is characteristically flamboyant, but what they share is the economic success story - how to negotiate financial difficulties heralding from humble backgrounds back in India and achieve considerable wealth in England, in the process becoming agents of Indian soft power as well as economic role models for an Indian economy that is rapidly aligning itself with the global free-market.

\section{Singing India in the Diaspora: The Diasporic Youth in $K 3 G$}

$D D L J$ built upon and embellished pre-existing narrative structures and imaginaries of Hindi popular cinema; inaugurated Bollywood as an "eclectic and hybrid" (Dwyer, 2010, p. 383), "high profile, export-oriented Bombay film" (Vasudevan, 2011a, p. 7); and thus laid the groundwork for subsequent high-budget and equally export-targeted Bollywood films to emerge. One such postDDLJ export-oriented Bollywood release was the 2001 film Kabhi Khushi Kabhie Gham... (Sometimes Happiness, Sometimes Sadness) (henceforth $K 3 G$ ), which drew upon the space carved by the success of $D D L J$ for the representation of diasporic young people in India's public culture. Reminiscent of the 'feudal family romance' (Prasad, 1998), a popular genre of Hindi films since 1950 s, the plot of $K 3 G$ progresses from patriarchal status quo to a state of crisis, precipitated by a 
filial rebellion. The narrative closure is brought about by overcoming the crisis and restoring the rule of the patriarch with minor diachronic changes, as the film poster announced itself with the tagline "It's All About Loving Your Parents." The diasporic space embodied in $K 3 G$ neither triggered the crisis in the plot nor played host to its resolution, but without its diasporic subplot, the denouement would not have achieved its immediacy and emotional impact.

Directed by Karan Johar, $K 3 G$ tells the story of the Raichand family, a wealthy upper-caste Hindu family in northern India, comprising of the patriarch Yashvardhan, a business magnate, his wife Nandini, and their two sons - Rahul and Rohan. Rahul was adopted by the couple, and both their sons are shown to be treated with lavish gifts and luxuries by the Raichands. Amidst its ostentatious family parties and religious festivals, the crisis in the Raichand household is precipitated when elder son Rahul defies his father's dictates and marries Anjali Sharma who belongs to a lower social class and hence is deemed by Yashvardhan to be an unsuitable match for his son. As a result of this defiance, Rahul is disowned by Yashvardhan, and he leaves the family home and goes to London with his newlywed wife Anjali, sister-in-law Pooja, and Daijan Sayeeda - Rahul and Rohan's erstwhile nanny. London becomes a refuge that Rahul and Anjali adopt as they are expelled from the family by the patriarch on account of Rahul's non-conformity to the 'sanskriti' (culture), 'sanskār' (values), and 'paramparā' (traditions) of the Raichand family. The 
plot then shifts to ten years later, and this temporal jump in the narrative is accompanied by a spatial reconfiguration. Rahul's home in London becomes a space where the patriarchal whims of Yashvardhan no longer function but where he has an absent presence. Rahul and Anjali are shown to have settled in Hampstead - one of the most expensive neighborhoods in London - as a way of signifying diasporic wealth, and success, further bolstering the economic and symbolic success story of the diaspora that the post-liberalization India wants to see and hear about. The narrative crisis in $K 3 G$ is resolved by the return of Rahul and family to India and their (re)induction into the folds of the Raichand family. By rendering such narratives of diasporic success and return, Bollywood contributes to the refashioning of a transnational Indian-ness that mediates the extension of cultural and political citizenship to the diaspora for the benefit of the Indian nationstate (Mohammad, 2007).

This 'feudal family romance' of $K 3 G$ was introduced through its title track, infused with religious overtones, praising the Hindu deities of 'Ram-Sita,' indirectly alluding to Rahul-Anjali's return from London with the aid of Rahul's mirroring the way their mythic counterparts Ram and Sita returned from exile with Ram's brother Lakshman. Rini Bhattacharya Mehta has argued that by its simultaneous glorification of patriarchal control and transnational modernity, films like $K 3 G$ have "pushed Bollywood's ideology to the far-right" (Mehta, 2011, p. 9). The "modernized neoliberal patriarchy" (Mehta, 2011, p. 9) that shapes this transnational 'feudal family romance' 
is exemplified by Yashvardhan - a successful entrepreneur who runs the 'Raichand Empire.'

Business houses like the Raichands reaped the long-term benefits of the liberalization of Indian economy, and through its family practices, Raichands seek to retain their social privileges by policing the boundaries between them and the middle-class Sharmas (Anjali's family). Class boundaries are policed here through the regulation of marital relations, which in turns shapes the direction of travel for the inter-generational ties between Yashvardhan and his adult son. In $K 3 G$ 's diasporic space, such neoliberal patriarchy exemplified by, but not limited to, Yashvardhan aligns itself with transnational Hindu religious symbolisms.

Rahul's wife Anjali, played by Kajol, is depicted as a sari-clad north-Indian daughter-inlaw and mother who has taken upon herself the responsibility of assuring that her son Krish (an allusion to the Hindu god Krishna) does not fail in his performance of transnational 'Indian-ness.' Her parenting practices and social reproductive work within the home are glorified as the legitimate vehicle for the transmission of this transnational 'Indian-ness' across generations in the diaspora. She dreams, in a way redolent of Baldev's yearnings in $D D L J$, about leaving the 'alien' country and going back to her husband's family home in India where she belongs. In a curious juxtaposition, Anjali's sister Pooja wears western attire, goes partying with friends, has shortened her name to an anglicized Poo, and is not far removed from Preeti of Purab Aur Paschim. Rahul 
continuously complains about Poo's choice of clothes and even attempts to literally cover her up in the presence of a supposed stranger, Rohan. Keeping with its ideology, $K 3 G$, much like its predecessors, attempts a simple binary of inter-opposing characterizations of the Indian diasporic woman. Eventually, Poo has to put on a salwar kameez and sing "Jai Jagadisha Harey" in the early morning prayers with kurta-clad Rohan, to achieve her family's approval and redeem herself as an Indian woman. In the same scene, Rohan tells Rahul: "you are seeing her [Poo] for the first time fully clothed, that's why you can't recognize her; she is your sister-in-law." Soon afterwards, Rahul confides in his wife that "Poo looks pretty in full clothes." The character of Poo also resonates with the character of Anjali in Johar's earlier film Kuch Kuch Hota Hai (Something Happens, 1998) where she was courted and married by Rahul only after her transformation from a short-haired tomboyish basketball player into a sari-clad long-haired Indian woman who holds workshops for children and sings "Jai Jagadisha Harey" in the assembly. As we shall see later, Poo prefigures the character of Jazz, aka Jasmeet, in Namastey London.

When Rohan first arrives in London in search of his brother Rahul who had been expelled from the family by their father, a hawk's eye view of the city is played out with India's national song "Vande Mataram" playing in the backdrop. The sights of various consumer brands including Starbucks and Virgin flashes by, as Rohan encounters Bharatanatyam dancers and a group of young women waving their scarves that correspond to the tricolor of the Indian flag. Aswin 
Punathambekar sees in such projections "an embodiment of a 'super-Indian', whose Indianness transcends both that of the resident and non-resident Indian" (Punathambekar, 2005). The Indian dancers on the streets of London also speak of the then emerging South Asian song and dance scene in Britain (Sharma, Hutnyk, \& Sharma, 1996), which has more recently translated into Bollywood flash mobs in London.

In $K 3 G$, Anjali's constant fear and concern regarding her UK-born son Krish's living an 'English' life is made evident throughout the film. She fears Krish would become 'angrez' (English) and laments that he is not growing up in India. During Krish's annual day at school, the children take to the stage to sing "Do Re Mi" from The Sound of Music. On stage, Krish declares “this is for you, mom," and instead of singing 'Do Re Mi,' surprises everyone by singing the Indian national anthem "Jana Gana Mana" with his friends, precipitating immense pride and elation among his family members. Interestingly, the white English guests are also seen to rise up and place their hands on their hearts, in a show of respect to India's national anthem. When Krish, in his heavily accented Hindi, is unable to complete the song, Anjali sings the last line and rushes to embrace him with tears in her eyes while the patriotic tunes of "Vande Mataram" (Hail to the Motherland India) plays in the background and the guests applaud. As the scene unfolds, the tune fades into "Saare Jahan se Accha Hindustaan Hamara" (Better than any place in the universe, is 
our India). The scene, therefore, fits together three conspicuously patriotic songs about India and, through Anjali's actions, merge together the image of the biological mother with the symbolism of the nation as mother. This polysemic figure of the mother is conjured at a crucial juncture in the plot, as Rahul is to meet his own (adopted) mother Nandini soon afterwards. The geo-body of the Indian nation-state is resurrected in the diaspora through these chains of significations, with Rohan's entry to London being greeted by the Indian national song in the background and UKborn Krish singing India's national anthem with his white friends. The expulsion of Rahul from India is translated into his actual separation from his adopted mother Nandini while Anjali's dedication to his son's cultural socialization is glorified. The mother, as a gendered and generational identity, is called upon throughout $K 3 G$ as the vanguard of Indian tradition and the force behind diasporic children's cultural socialization.

\section{Namastey London and the Return of East Versus West}

Directed by Vipul Amrutlal Shah, Namastey London (Hello London, 2007) provides another window into diasporic youth subjectivities as espoused in the early decades of Bollywood. Its plot exclusively pursues the life of a second-generation British Indian youth named Jasmeet Malhotra. Jasmeet, much like Pooja of $K 3 G$, has adopted an Anglicized name Jazz. She spells out in 
unequivocal terms all that was left unsaid in the earlier two texts discussed above. When her friend Laila, who is herself a British Indian, asks Jazz what her problem is in marrying an Indian, she spontaneously replies, "They are Indian; that's the problem." The friend, refusing to take this answer, angrily tells Jazz in Hindi, "What are you? You too are an Indian.” In reply, Jazz goes on to say in an accented Hindi:

I am British. I was not born in India. I have never been to India. My parents are citizens of the UK. Since the age of three, I have been singing the British national anthem 'God save the Queen'. I was born and brought up here. Therefore, my attitudes, my thinking, my likings are all British. How could I be an Indian?

Jazz's politics of belonging is a direct heir of and in some ways a return to the subjectivities embodied by Preeti in 1970's Purab Aur Paschim (East and West). In an earlier scene, Jazz asserts herself as British when being asked by an Indian taxi driver in London if she was "from India," to which she answers "No, I am from Harris Street." Soon afterwards, a subplot is introduced. This involves a second-generation British Pakistani youth Imran, who is reprimanded by his father Parvez for proposing to move in with his white girlfriend Susan without marriage. Pervez deems it morally incorrect and eventually expels Imran from the house. When Imran's and Jasmeet's fathers chat in a park, pondering whether they made a "mistake coming to England," Jazz's father Manmohan repents that he did not realize when his daughter became Jazz from Jasmeet. Later on, he regrets that he is "the Indian father of an English daughter." 
The divergence in diasporic subjectivities and politics of belonging depicted by Jazz, by Manmohan, and by Laila distinguishes this film from its predecessors. The second-generation British Indian youth is not subsumed into proclaiming Saare Jahan se Accha Hindustaan Hamara (Better than any place in the universe, is our India) like Krish repeatedly does in $K 3 G$ or in upholding Indian notions of izzat (honour) and sanskar (values) as Raj and Simran do in DDLJ. In a way, Namastey London is a more heterogeneous text, showcasing the multiple ways of enacting diasporic identities, but as we shall discuss later, those very divergences are at the end policed and collapsed into a singular positionality through the disciplining of Jazz's desires.

As the plot progresses, Jazz and her family visit India in an attempt to search for the lost ideals of Indian-ness and to reassert their Indian-origin identity. As they tour the religious and historical sites in India, Manmohan cultivates his ulterior motive of finding an eligible Indian groom for Jasmeet. In their search for a groom, the Malhotras travel to various cities in India only to return unsuccessful to their ancestral land of Punjab, where they fatefully meet Arjun (Akshay Kumar) in whom the father sees the perfect match for his daughter. While explaining to Jasmeet the advantages of the Indian arranged marriage system, Manmohan emphasizes that such arrangements are more stable than their Western counterparts. As this match-making unfolds, Arjun gets lost in a 'dream sequence' (Gopalan, 2002), a staple Bollywood device for diasporic settings, where he imagines Jasmeet wearing traditional Punjabi clothes and embracing the way of 
life in Punjabi villages. In an act of coercion, the Malhotra patriarch manages to get Jazz married to Arjun, in defiance of her choice. Jazz decides to surrender to her father's demands while she is in India, but upon returning to London, disowns Arjun as her husband, citing the legal invalidity of their nuptial in the UK.

While in London, Arjun attends a riverside party where Jazz is present with her white boyfriend Charlie. In that party, a certain Mr. John Pringle, whose father was an officer in the British East India Company, ridicules India. When introduced to Jazz by Charlie, Pringle is surprised by the fact that Indians have started keeping "fancy names" in an "attempt to be one of us," which he claims is done because "she doesn't want to be known as coming from the land of snake charmers." To this, Charlie adds that India is also the land of "chicken tandoori" and "call centers." This upsets Jazz, and Arjun asks her why these observations about India have affected someone who claims not to be an Indian. Arjun further declares that "wherever you stay, you will be an Indian." Eventually, Arjun and Jazz team up to introduce the 'real' India to the white British guests, as Arjun delivers an impassioned speech in Hindi which Jazz translates into English for guests. With the song "Saare Jahan Se Achha Hindustaan Hamara" (Better than any place in the universe, is our India) playing in the background, Arjun lists the various historical, socioeconomic, and cultural dimensions of contemporary India, including its religious tolerance, 
plurality, linguistic diversity, military prowess, and achievements in science and technology. The speech evidently impresses the Indian diasporic guests at the party. Arjun's speech resonates closely with the one given my Bharat at an Indian club in London in the film Purab Aur Paschim (1970). After being insulted by a diasporic Indian at the club who asserts that India's contribution to the world is zero, Bharat - who had recently moved to London from India to complete his studies - retorts by saying that India invented the zero which enabled the world to learn counting and then catalogues the achievements of India. He then sings what has now become a legendary patriotic song in India: "Hai preet jahan ki reet sada, Main geet wahan ke gaata hoon" (Where love has always been the culture, I sing songs of that country). In Namastey London, Jazz undergoes a change of heart soon after this speech and is redeemed when she embraces her Indian identity and elopes to rural Punjab with Arjun. Arjun, thus, manages to accomplish what Bharat in Purab aur Paschim and Rohan in $K 3 G$ had done: 'convert' British Indian women into accepting their gendered role within the family and the Indian nation-state in the process embracing a particular idea of India that rests on patriarchal control of women's desires. Consequently, all three films invest heavily in these male heroes and glorify them through their successful return 'home' to a neoliberal India that reconciles a liberal political economy with conservative social ideologies. 


\section{Conclusion}

Through close intertextual readings, this article has demonstrated how Indian diasporic youth in the UK are represented in popular Bollywood films, especially in the first decades of Bollywood.

The three main cinematic texts analyzed here speak to distinct points in India's post-1990s diaspora strategy where Bollywood has played an active role. The narratives bring into sharp relief how post-liberalization India has come to require the diaspora, symbolically and otherwise, in its efforts to reconfigure the nation-state from an aesthetic to a global 'brand' (Vasudevan, 2011a).

The films further illustrate how gender, sexuality, and nation are co-implicated in the way diasporic youth subjects are seen and treated within Bollywood's narrative economies. The British Indian youth is redeemed only when the desires of gendered diasporic subjects like Simran $(D D L J)$, Poo $(K 3 G)$, and Jazz (Namastey London) are successfully policed by their fathers and their (would-be) husbands. Such a positioning of India as a "nation rooted in an exotic, classical culture, that is still able to integrate seamlessly into a technology driven global political economy" (Radhakrishnan, 2008, p. 8) relies heavily on the diaspora to articulate such ideologies of 'global Indian-ness' through a certain brand of femininity. As women in these films navigate these gendered and generational structures (for example, father-daughter generational structures), they display forms of ephemeral agency to which our analysis has paid due attention. The various acts 
of disruption within the sphere of the home - the challenges to generational norms - that the gendered subjects in these films undertake at various points show how the exercise of their agency is context-dependent and context-bound. Furthermore, the analysis has demonstrated that Bollywood's cinematic history, with respect to British Indian youth, unfolds in a non-linear fashion. Although Anita in Lamhe (1991) and Simran in DDLJ embody a shift away from the caricature that is made of Preeti in Purab Aur Paschim, Poo in K3G and Jazz in Namastey London, at least in their pre-reformed state, are extrapolations of Preeti. As hedonistic and deracinated diasporic subject, they need the intervention of patriarchy to put them in their place and restore their respectable Indian femininity underpinned by 'sanskriti' (culture), 'sanskār' (values) and 'paramparā' (traditions), while Bharat, Rohan and Arjun carry out this function, and their maleprojects resolve the crises of patriarchy in Bollywood's diaspora narratives. In sum, the above analyses show that inter-generational practices in relation to long-distance Indian nationalism, social reproductive work within the diasporic household, and the policing of young women's marital relations are pivotal to the articulation and regulation of diasporic youth subjectivities in Bollywood films.

\section{REFERENCES}

Anwar, M. (1998). Between cultures: Continuity and change in the lives of young Asians. Routledge. 
Banaji, S. (2017). Children and media in India narratives of class, agency and social change. Routledge.

Baumann, G. (2004). Contesting culture: Discourses of identity in multi-ethnic London. Cambridge University Press.

Bose, B. (2017). The audacity of pleasure: Sexualities, literature and cinema in India. Three Essays Collective.

Brosius, C. \& Yazgi, N. (2007). 'Is there no place like home?': Contesting cinematographic constructions of Indian diasporic experiences. Contributions to Indian Sociology, 4(3), 355386. DOI: $10.1177 / 006996670704100303$.

Dwyer, R. (2014). Bollywood's India: Hindi cinema as a guide to contemporary India. Reaktion Books.

Dwyer, R. (2010). Bollywood's India: Hindi cinema as a guide to modern India. Asian Affairs, 41(3), 381-398. DOI: 10.1080/03068374.2010.508231.

Dwyer, R. (2000). 'Indian values' and the diaspora: Yash Chopra's films of the 1990s. West Coast Line, 34(2), 6-27.

Ghuman, P. A. S. (1991). Best or worst of two worlds?: A study of Asian adolescents. Educational Research, 33(2), 121-132.

Ghuman, P. A. S. (1994). Coping with two cultures: British Asian and Indo-Canadian adolescents. Multilingual Matters Ltd.

Gopalan, L. (2002). Coitus interruptus and love story in Indian cinema. In V. Dehejia (Ed.). Representing the body: Gender issues in Indian art (pp. 124-139). Kali for Women.

Habib, I. H. (2006). Indians in Shakespeare's England as 'the first-fruits of India': Colonial effacement and postcolonial reinscription. Journal of Narrative Theory, 36(1), 1-19. DOI: 10.1353/jnt.2006.0019.

Ho, L. E. E. (2011). 'Claiming' the diaspora. Progress in Human Geography, 35(6), 757-772. DOI: $10.1177 / 0309132511401463$.

Ho, L. E. E., Hickey, M. \& Yeoh, S. A. B. (2015). Special issue introduction: New research directions and critical perspectives on diaspora strategies. Geoforum, 59, 153-158. DOI: 10.1016/j.geoforum.2014.12.006.

Huq, R. (2003). From the margins to mainstream?: Representations of British Asian youth musical cultural expression from Bhangra to Asian underground music. Young, 11(1), 2948. DOI: $10.1177 / 1103308803011001074$. 
Joshi, S. A. (2014). Transgressing the moral universe: Bollywood and the terrain of the representable. In V. Kishore, A. Sarwal, \& P. Patra (Eds.). Bollywood and its other(s): Towards new configurations (pp. 41-54). Palgrave Macmillan.

Mani, B. \& Varadarajan, L. (2005). 'The largest gathering of the global Indian family': Neoliberalism, nationalism, and diaspora at Pravasi Bharatiya Divas. Diaspora: A Journal of Transnational Studies, 14(1), 45-74. DOI: 10.1353/dsp.0.0006

Mehta, R. B. (2011). Bollywood, nation, globalization: An incomplete introduction. In R. B. Mehta \& R. V. Pandharipande (Eds.). Bollywood and globalization: Indian popular cinema, nation, and diaspora (pp. 1-14). Anthem Press.

Modood, T. (2007). Britishness out of immigration and anti-racism. In B. Chandra \& S. Mahajan (Eds.), Composite culture in a multicultural society (pp. 32-49). Pearson Longman.

Mohammad, R. (2007). Phir bhi dil hai Hindustani (Yet the heart remains Indian): Bollywood, the 'homeland' nation-state, and the diaspora. Environment and Planning D: Society and Space, 25(6), 1015-1040. DOI: 10.1068/d441t.

Mishra, V. (2008). Bollywood cinema: A critical genealogy. Asian Studies Institute.

Nandy, A. (Ed). (1998). The secret politics of our desires: Innocence, culpability and popular cinema. Zed Books.

Office for National Statistics. (2014). Census 2011. https://www.nomisweb.co.uk/census/2011/key_statistics_uk

Prasad, M. M. (1998). Ideology of the Hindi film: A historical construction. Oxford University Press.

Punathambekar, A. (2005). Bollywood in the Indian-American diaspora: Mediating a transitive logic of cultural citizenship. International Journal of Cultural Studies, 8(2), 151-173. DOI: $10.1177 / 1367877905052415$.

Radhakrishnan, S. (2008). Examining the "global" Indian middle class: Gender and culture in the Silicon Valley/Bangalore circuit. Journal of Intercultural Studies, 29(1), 7-20. DOI: $10.1080 / 07256860701759915$.

Raj, D. S. (2015). The overseas citizen of India and emigrant infrastructure: Tracing the deterritorializations of diaspora strategies. Geoforum, 59, 159-168. DOI: 10.1016/j.geoforum.2014.11.015.

Rajadhyaksha, A. (2003). The 'Bollywoodization' of the Indian Cinema: Cultural nationalism in a global arena. Inter-Asia Cultural Studies, 4(1), 25-39. DOI: 10.1080/1464937032000060195.

Sharma, S. Hutnyk, J. \& Sharma, A. (Eds.). (1996). Dis-orientating rhythms: The politics of the new Asian dance music. Zed.

Thomas, R. (2015). Bombay before Bollywood: Film city fantasies. SUNY Press. 
Thussu, D. K. (2016). The soft power of popular cinema - The case of India. Journal of Political Power, 9(3), 415-429. DOI: 10.1080/2158379X.2016.1232288.

Vasudevan, R. (2011a). The meanings of 'Bollywood.' In R. Dwyer \& J. Pinto (Eds.), Beyond the boundaries of Bollywood: The many forms of Hindi cinema (pp. 3-29). Oxford University Press.

Vasudevan, R. (2011b). The melodramatic public: Film form and spectatorship in Indian cinema. Palgrave Macmillan.

Visram, R. (1986). Ayahs, lascars and princes: Indians in Britain, 1700-1947. Pluto Press. 